\title{
Comparison between histopathologic features of leprosy in reaction lesions in HIV coinfected and non-coinfected patients*
}

\author{
Carla Andréa Avelar Pires ${ }^{1,2}$ \\ Maraya de Jesus Semblano Bittencourt ${ }^{1}$ \\ Marília Brasil Xavier ${ }^{1,2}$ \\ DOI: http://dx.doi.org/10.1590/abd1806-4841.20153048
}

Mario Fernando Ribeiro de Miranda ${ }^{1}$

Arival Cardoso de Brito ${ }^{1}$

\begin{abstract}
BACKGROUND: Leprosy and HIV are diseases that have a major impact on public health in Brazil. Patients coinfected with both diseases, appear to be at higher risk to develop leprosy reactions.

OBJECTIVE: The aim of this study is to describe the histopathological aspects of cutaneous lesions during reactional states in a group of patients with HIV-leprosy coinfection, compared to patients with leprosy, without coinfection.

METHODS: Two groups were established: group 1 comprised of 40 patients coinfected with HIV-leprosy; group 2, comprised of 107 patients with leprosy only. Patients presenting reactional states of leprosy had their lesions biopsied and comparatively evaluated. RESULTS: Reversal reaction was the most frequent feature in both groups, with dermis edema as the most common histopathological finding. Giant cells were seen in all group 1 histopathological examinations. Dermis edema was the most common finding in patients with erythema nodosum leprosum.

CONCLUSIONS: Few histopathological differences were found in both groups, with reversal reaction as the most significant one, although this fact should be analyzed considering the predominant BT clinical form in the coinfected group and BB form in the group without HIV. Larger prospective studies in patients with HIV-leprosy coinfection are needed to confirm and broaden these results.

Keywords: Coinfection; HIV; Histology; Leprosy
\end{abstract}

\section{INTRODUCTION}

Leprosy and infection by human immunodeficiency virus (HIV) represent infectious diseases that still constitute important global health problems and continue to cause social stigma in many societies. Patients coinfected with HIV seem to develop leprosy reactions even during severe immunodeficiency states. ${ }^{1}$

Leprosy is a disease that is distinguished by cutaneous lesions and neural damage in patients. The clinical spectrum of the disease depends on the type of immune response that the host presents against the bacteria, and according to Ridley and Jopling's classification, there are two diametrically opposed forms, tuberculoid (TT) and lepromatous (LL). ${ }^{2}$ While in TT forms the patient presents a well-developed cellular immune response that can halt the multiplication of bacilli, in LL forms the cellular response is deficient, leading to swift replication of bacilli. There are also intermediate clinical forms, defined as borderline (BT, $\mathrm{BB}, \mathrm{BL})$, which are immunologically unstable. ${ }^{3,4}$
Type 1 reactions or reversal reactions (RR) are of the delayed-type hypersensitivity, which occur mainly in the borderline or dimorphic leprosy clinical forms. Mycobacterium leprae antigens have been found in nerves and skin of patients with this type of reaction. The antigens were found in the Schwann cells and in macrophages. Type 2 reactions or erythema nodosum leprosum (ENL) reactions occur most commonly in borderline lepromatous leprosy and in lepromatous leprosy clinical forms. In the latter, humoral immunity is predominantly involved, with the presence of circulating immune complexes and high levels of plasma TNF- $\alpha .{ }^{4,5}$

Mycobacterium leprae does not seem to accelerate the decline of immune function when associated with HIV infection, as it often happens with tuberculosis coinfection. Reactional states may occur more frequently in individuals with HIV coinfection, but there are still many conflicting data regarding increased reaction frequency in this group. ${ }^{5}$

\footnotetext{
Received on 10.08.2013.

Approved by the Advisory Board and accepted for publication on 03.02.2014

* Work performed at the Tropical Medicine Center at Universidade Federal do Pará (UFPA) - Belém (PA), Brazil.

Financial support: None.

Conflict of interests: None.

Universidade Federal do Pará (UFPA) - Belém (PA), Brazil.

Universidade do Estado do Pará (UEPA) - Belém (PA), Brazil.

(C)2015 by Anais Brasileiros de Dermatologia
} 
Granulomatous response is morphologically identical in patients with leprosy and both HIV-negative and HIV-positive. Epithelioid granulomas are present in patients with tuberculoid pole clinical forms, while foamy macrophages are commonly observed in patients with lepromatous pole clinical forms. ${ }^{1,6,7}$ There are still few data regarding the morphological aspects of leprosy reactions in the coinfected group. Superficial dermis edema, edema within disorganized granulomas and the presence of giant cells are observed in patients with type 1 reactions. Dermis edema is also seen in type 2 reactions, with neutrophil infiltration and other characteristic features of pre-existing lepromatous lesions with or without vasculitis and usually with panniculitis.?

Lockwood and colleagues (2008) conducted an extensive study in which 4 pathologists observed, at different occasions, the histopathological features of 99 patients with reversal reactions and 52 controls without leprosy reactions, in an attempt to standardize the key criteria for the diagnosis of reversal reaction that have been used in current studies. ${ }^{8}$ Among them, we highlight dermis edema and the presence and size of giant cells.

Several studies describe the histopathological characteristics of patients during reactional state, but because this is an inflammatory condition, some have pre-defined criteria that are most difficult to standardize. In this condition, standardization of criteria becomes extremely important, especially for those who are not familiar with the diagnosis and also because of the frequent uncertainties in differentiating reactive states from disease relapses. ${ }^{9}$ The aim of this study is to describe histopathological aspects of cutaneous lesions during the reactional states in a group of patients with HIV / AIDS and leprosy coinfection, comparing them to leprosy patients without HIV infection.

\section{MATERIALS E METHODS}

A clinical cohort, with patients seen at the Tropical Medicine Center (NMT) Dermatology Clinic, at Federal University of Pará (UFPA) in Belém, Pará, Brazil was performed. Time of patient accrual to ensure participation in the study ranged between January 2007 and March 2011. Each patient was followed for a period of two years in order to observe the occurrence of reactional episodes. Consultations occurred once every two weeks for those patients with leprosy reactions, or monthly, for those who did not developed them.

Sample size (n) was not pre-determined, since ours is a referral center for the treatment of dermatosis that are of sanitary interest. Two groups were organized in the study: the first (Group 1) consisted of 40 patients coinfected with HIV/AIDS and leprosy, 15 of those patients presented episodes of leprosy reaction, and had their lesions biopsied. The other group (Group 2) consisted of 107 leprosy patients without HIV, 60 presenting reactional episodes, which were also biopsied, although only 49 provided sufficient material for morphological analysis.

Biopsies were performed with a $4 \mathrm{~mm}$ punch, reaching hypodermis depth; the material was fixed in $10 \%$ formalin and placed in a paraffin block for further cutting and staining with hematoxylin-eosin and Fite-Faraco method, and subsequently analyzed by two professionals: a dermatopathologist and a pathologist with expertise in leprosy. Regarding cell count gradation, it was considered $1+$ when 1 to 6 cells per field (40x magnification) were counted and $2+$ when more than 6 cells per field were observed. As for the edema within the granuloma, it was considered 1+ when causing up to $50 \%$ granuloma dissociation and $2+$ when dissociation was greater than $50 \%$.

Patients were referred from designated units, specialized in the diagnosis and treatment of patients with HIV/AIDS, and were already in clinical followup for their HIV infection. The diagnosis of leprosy and its reactional states was determined by dermatologists with expertise in this disease, based on clinical and semiological aspects recommended by the decree of the Brazilian Ministry of Health $N^{\mathrm{O}}$. 3125 of 7 October 2010, and patients also underwent lesion biopsies with histopathological exams. Clinical presentations were based on the classification described by Ridley and Jopling., ${ }^{2,10,11}$

Statistical analysis was performed using the 5.0 version of BioEstat ${ }^{\circledR}$ program. To generate statistics proving the association of relevant study variables, we considered a 95\% confidence interval (CI) and 5\% $\alpha$ level ( $p$-value $\leq 0.05$ ). We considered $p>0.05$ to confirm the null hypothesis $(\mathrm{H} 0)$ and $\mathrm{p} \leq 0.05$ to reject it. $\mathrm{T}$ test was applied to compare quantitative variables between the analyzed groups. Chi-square, $G$ test and exact Fisher test were used to compare $\mathrm{n}$ independent samples, whose observed proportions in the various modalities were arranged in lxc contingency tables, used to calculate the proportions in different categories and determine whether they were associated. To estimate how much a given variable contributed to the occurrence of a certain clinical outcome, we used the relative risk as a bivariate analysis of association measure.

The research project was approved by the Tropical Medicine Center's Ethics Committee on Human Research under protocol number 001/2011. All study participants signed the consent form.

\section{RESULTS}

Of 40 patients included in Group 1 (HIV/AIDS and leprosy coinfection), and 107 patients in Group 2 
(patients with leprosy who were HIV seronegative), $67.5 \%$ and $67.3 \%$, respectively, were males, with predominant age range between 31-59 years, and mean age of 37 years in both groups (Table 1 ).

The predominant operational classification in the coinfected group was paucibacillary with $70 \%$ of cases, while $80.4 \%$ in Group 2 were multibacillary cases $(p<0.0001)$. Leprosy patients without HIV infection were more likely to progress to multibacillary forms compared to coinfected patients (relative risk = 3.0) (Table 1).

In Group 1, the predominant clinical presentation in $45 \%$ of the cases was BT, while in Group 2 patients presented clinical type BB more frequently, with $40.2 \%$ of cases ( $p<0.0001$ ) (Table 1 ).

In the coinfected group, only $37.5 \%$ had any episode of leprosy reaction and in the group of patients without HIV, $56.1 \%$ had leprosy reactions ( $p$ $=0.0026)$. The coinfected patients had a lower risk of developing leprosy reaction $(\mathrm{RR}=0.47)$ (Table 2$)$.

In both groups, the most frequent reaction was type 1 or reversal reaction: $86.7 \%$ in the coinfected group and $56.6 \%$ in the group without coinfection ( $\mathrm{p}$ $=0.0750$ ). In Group 1, 17.5\% of patients had acute neuritis versus $25.2 \%$ in Group 2, although this data was not statistically significant (Table 2).

Regarding reversal reaction, which was the more prevalent one in both groups, coinfected patients had dermatological lesions expected for each clinical form, typically erythematous and infiltrated, besides a clinical course similar to that of HIV seronegative patients (Figure 1).
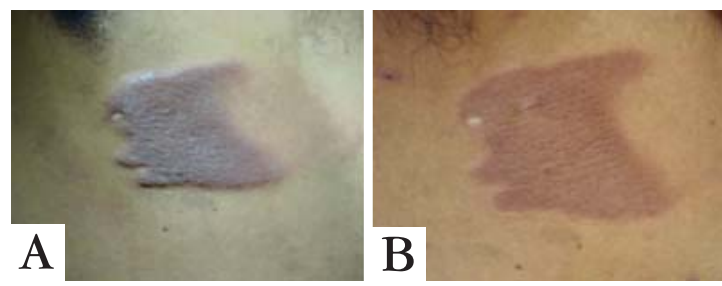

FIGURE 1: A. Lesion in a patient coinfected with HIV/leprosy, Borderline-Tuberculoid (BT) form, in reversal reaction (RR). B. Lesions in regression after 30 days of treatment with prednisone

TABLE 1: Distribution of patients according to gender, age, operational and clinical classification*

\begin{tabular}{|c|c|c|c|c|c|}
\hline \multirow[t]{3}{*}{ General characteristics } & \multicolumn{4}{|c|}{ Evaluated groups } & \multirow[t]{3}{*}{ p-value } \\
\hline & \multicolumn{2}{|c|}{ Group I (HIV-leprosy) } & \multicolumn{2}{|c|}{ Group II (leprosy) } & \\
\hline & $\mathbf{N}$ & $\%$ & $\mathbf{N}$ & $\%$ & \\
\hline \multicolumn{6}{|l|}{ Gender } \\
\hline Male & 27 & 67.5 & 72 & 67.3 & \multirow{3}{*}{$\begin{array}{l}\text { Chi-square } \\
\quad p=0.8623\end{array}$} \\
\hline Female & 13 & 32.5 & 35 & 32.7 & \\
\hline Total & 40 & 100 & 107 & 100 & \\
\hline \multicolumn{6}{|l|}{ Age Range (years) } \\
\hline$\leq 15$ & 1 & 2.5 & 12 & 11.2 & \multirow{5}{*}{$\begin{array}{l}G \text { test } \\
\qquad p=0.0872\end{array}$} \\
\hline 16 to 30 & 10 & 25.0 & 31 & 29.0 & \\
\hline 31 to 59 & 28 & 70.0 & 55 & 51.4 & \\
\hline$\geq 60$ & 1 & 2.5 & 9 & 8.4 & \\
\hline Total & 40 & 100 & 107 & 100 & \\
\hline \multicolumn{6}{|l|}{ Age (years) } \\
\hline Mean \pm Standard deviation & $37.8 \pm 10.4$ & $36.2 \pm 16.5$ & & & $\begin{array}{l}\text { T test } \\
p=0.4897\end{array}$ \\
\hline \multicolumn{6}{|l|}{ Operational classification } \\
\hline Paucibacillary & 28 & 70 & 21 & 19.6 & \multirow{3}{*}{$\begin{array}{l}\text { Relative risk }=3.0 \\
p<0.0001 \\
95 \% \mathrm{CI}=2.0-4.6\end{array}$} \\
\hline Multibacillary & 12 & 30 & 86 & 80.4 & \\
\hline Total & 40 & 100 & 107 & 100 & \\
\hline \multicolumn{6}{|l|}{ Clinical Classification } \\
\hline Pure neural & 0 & 0.0 & 3 & 2.8 & \multirow{8}{*}{$\begin{array}{l}\text { G test } \\
p<0.0001\end{array}$} \\
\hline Indeterminate & 3 & 7.5 & 4 & 3.7 & \\
\hline TT & 7 & 17.5 & 14 & 13.1 & \\
\hline BT & 18 & 45.0 & 11 & 10.3 & \\
\hline $\mathrm{BB}$ & 10 & 25.0 & 43 & 40.2 & \\
\hline $\mathrm{BL}$ & 2 & 5.0 & 21 & 19.6 & \\
\hline LL & 0 & 0.0 & 11 & 10.3 & \\
\hline Total & 40 & 100 & 107 & 100 & \\
\hline
\end{tabular}


TABLE 2: Distribution of patients according to the clinical characteristics of leprosy reactions

\begin{tabular}{|c|c|c|c|c|c|}
\hline \multirow[t]{3}{*}{ Clinical characteristics } & \multicolumn{4}{|c|}{ Evaluated groups } & \multirow[t]{3}{*}{ Statistical tests } \\
\hline & \multicolumn{2}{|c|}{ Group I (HIV-leprosy) } & \multicolumn{2}{|c|}{ Group II (leprosy) } & \\
\hline & $\bar{N}$ & $\%$ & $\mathrm{~N}$ & $\%$ & \\
\hline \multicolumn{6}{|l|}{ Leprosy reaction } \\
\hline Yes & 15 & 37.5 & 60 & 56.1 & \multirow{3}{*}{$\begin{array}{l}\text { Relative risk }=0.47 \\
p=0.0026 \\
95 \% C I=0.28-0.79\end{array}$} \\
\hline No & 25 & 62.5 & 47 & 43.9 & \\
\hline Total & 40 & 100 & 107 & 100 & \\
\hline \multicolumn{6}{|l|}{ Reaction type } \\
\hline Type I & 13 & 86.7 & 34 & 56.6 & \multirow{4}{*}{$\begin{array}{l}\mathrm{G} \text { Test } \\
\mathrm{p}=0.0750\end{array}$} \\
\hline Type II & 2 & 13.3 & 22 & 36.7 & \\
\hline Type I e II & 0 & 0 & 4 & 6.7 & \\
\hline Total & 15 & 100 & 60 & 100 & \\
\hline \multicolumn{6}{|l|}{ Neuritis } \\
\hline Present & 7 & 17.5 & 27 & 25.2 & \multirow{3}{*}{$\begin{array}{l}\text { Chi-square } \\
p=0.4414\end{array}$} \\
\hline Absent & 33 & 82.5 & 80 & 74.8 & \\
\hline Total & 40 & 100 & 107 & 100 & \\
\hline
\end{tabular}

TABLE 3: Distribution of patients with reversal reaction according to histopathological characteristics

\begin{tabular}{|c|c|c|c|c|c|}
\hline \multirow{3}{*}{$\begin{array}{l}\text { Histopathological characteristics } \\
\text { in patients with } R R\end{array}$} & \multicolumn{4}{|c|}{ Evaluated groups } & \multirow[t]{3}{*}{ Statistical tests } \\
\hline & \multirow{2}{*}{\multicolumn{2}{|c|}{$\begin{array}{l}\text { Group I } \\
\text { (HIV-leprosy) }\end{array}$}} & \multirow{2}{*}{\multicolumn{2}{|c|}{$\begin{array}{l}\text { GroupII } \\
\text { (Leprosy) }\end{array}$}} & \\
\hline & & & & & \\
\hline & $\mathbf{N}$ & $\%$ & $\mathbf{N}$ & $\%$ & \\
\hline \multicolumn{6}{|l|}{ Dermis edema } \\
\hline Yes & 13 & 100.0 & 33 & 100.0 & - \\
\hline No & 0 & 0.0 & 0 & 0.0 & \\
\hline Total & 13 & 100.0 & 33 & 100.0 & \\
\hline \multicolumn{6}{|l|}{ Edema within granulomas } \\
\hline $1+$ & 0 & 0.0 & 14 & 42.4 & Exact Fisher \\
\hline $2+$ & 13 & 100.0 & 19 & 57.6 & $p=0.0042$ \\
\hline Total & 13 & 100.0 & 33 & 100.0 & \\
\hline \multicolumn{6}{|l|}{ Granuloma fragmentation degree } \\
\hline$\leq 10 \%$ & 0 & 0.0 & 2 & 6.3 & G Test \\
\hline 11 to $50 \%$ & 13 & 100.0 & $\overline{7}$ & 21.9 & $p<0.0001$ \\
\hline$>50 \%$ & 0 & 0.0 & 23 & 71.9 & \\
\hline Total & 13 & 100.0 & 32 & 100.0 & \\
\hline \multicolumn{6}{|l|}{ Giant cells } \\
\hline Yes & 13 & 100.0 & 15 & 45.5 & Exact Fisher \\
\hline No & 0 & 0.0 & 18 & 54.5 & $p=0.0005$ \\
\hline Total & 13 & 100.0 & 33 & 100.0 & \\
\hline \multicolumn{6}{|l|}{ Giant cells - Gradation } \\
\hline $1+$ & 0 & 0.0 & 14 & 93.3 & Exact Fisher \\
\hline $2+$ & 13 & 100.0 & 1 & 6.7 & $p<0.0001$ \\
\hline Total & 10 & 100.0 & 15 & 100.0 & \\
\hline
\end{tabular}

Regarding the histopathologic findings of patients with reversal reaction, we emphasize dermis edema, which was present in all patients of both groups. As for its gradation, edema within the granulomas was rated as $2+$ in $57.6 \%$ of patients without HIV, and in $100 \%$ of patients from the coinfected group ( $p=0.0057)$. Regarding the degree of granuloma fragmentation, $71.9 \%$ of non-coinfected patients had more than $50 \%$ fragmentation, while all coinfected patients $(\mathrm{p}<0.0001)$ presented fragmentation range between 11 and 50\% (Figure 2 and Table 3).

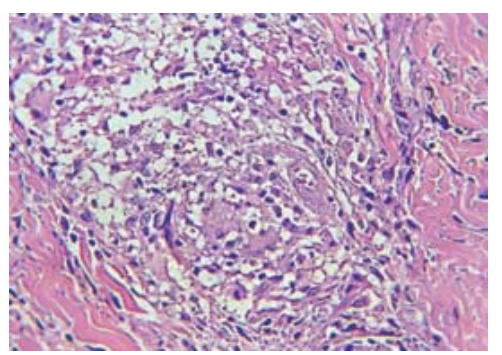

FIGURE 2:

Fragmented granuloma in patients with HIV/leprosy c o i n f e c tion. Photomicrography in HE with 40x augmentation 
Concerning patients who developed reversal reaction, giant cells were present in $45.5 \%$ of leprosy patients without HIV and $100 \%$ of coinfected patients $(p=0.0006)$. With reference to gradation, $93.3 \%$ of noncoinfected patients had 1+ degree, while $100 \%$ of the coinfected group presented $2+$ giant cells in their granulomas $(\mathrm{p}=0.0006)$ (Figure 3$)$.

With regard to the histopathological characteristics of patients with ENL, dissimilar to reversal reactions, none of the findings between groups had statistical significance. Among the main features, dermis edema was present in only two patients of Group 1 who had ENL, and in $56.3 \%$ of patients in Group 2 $(p=0.66)$. Those two patients in Group $1(100 \%)$ presented vasculitis and panniculitis, while of the 16 patients in Group 2, 62.5\% and 56.3\% had these features respectively ( $\mathrm{G}$ test, $\mathrm{p}=0.7864, \mathrm{p}=0.6606$ ) (Table 4 ).

Regarding the presence and degree of neutrophils and plasma cells, all patients in both groups had these cells in the maximum degree (2+) (Table 4).

\section{DISCUSSION}

Clinical and epidemiological studies of leprosy, with or without coinfection, do not show significant preference regarding gender, however in most studies the involvement of male patients is predominant. ${ }^{12,13}$ The adult age group from 31 to 59 years was prevalent in both groups (Group 1 - 70\% and Group 2 - 51.4\%), coinciding with data from the literature. ${ }^{14}$
The predominance of paucibacillary forms in the group coinfected with HIV-leprosy (relative risk=3.0), observed in this study, is a situation already well documented. ${ }^{15-18}$ The predominant clinical form was borderline-tuberculoid (BT) (45\%). The largest case series on HIV-leprosy coinfection described to date were conducted in Brazil, and the most of them also reports the prevalence of borderline-tuberculoid forms. ${ }^{6,13,17,18,19,20}$ In the no ncoinfected group, there was

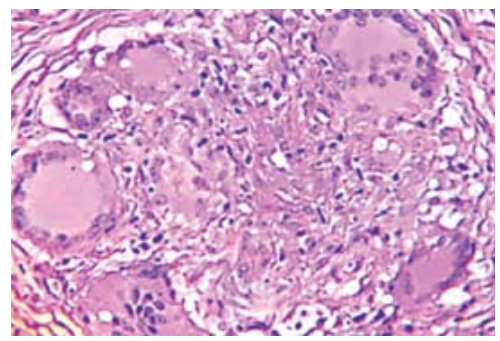

FIGURE 3:

Giant cells with increase in size and number, in a patient coinfected with HIV/leprosy. Photomicrography in HE with 40x augmentation

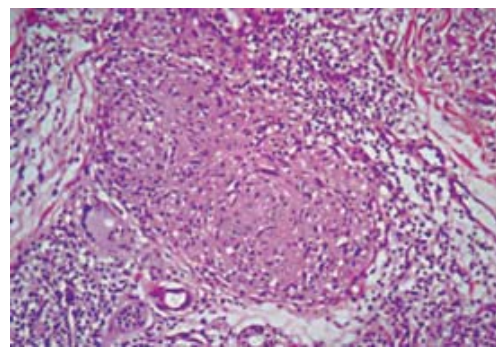

FIGURE 4:

Epithelioid granuloma, lymphocytes in the perigranuloma area and dermis edema in a patient coinfection with HIV / leprosy. Photomicrography in HE with 40x augmentation

TABLE 4: Distribution of patients with ENL according to histopathological characteristics

\begin{tabular}{|c|c|c|c|c|c|}
\hline \multirow{3}{*}{$\begin{array}{l}\text { Histopathological characteristics } \\
\text { in patients with ENL }\end{array}$} & \multicolumn{4}{|c|}{ Evaluated groups } & \multirow{3}{*}{ Statistical tests } \\
\hline & \multicolumn{2}{|c|}{$\begin{array}{l}\text { Group I } \\
\text { (HIV-leprosy) }\end{array}$} & \multicolumn{2}{|c|}{$\begin{array}{l}\text { Group II } \\
\text { (Leprosy) }\end{array}$} & \\
\hline & $\mathbf{N}$ & $\%$ & $\mathbf{N}$ & $\%$ & \\
\hline \multicolumn{6}{|l|}{ Dermis edema } \\
\hline Yes & 2 & 100.0 & 9 & 56.3 & \multirow{3}{*}{$\begin{array}{l}\text { Exact Fisher } \\
\mathrm{p}=0.4967\end{array}$} \\
\hline No & 0 & 0.0 & 7 & 43.8 & \\
\hline Total & 2 & 100.0 & 16 & 100 & \\
\hline \multicolumn{6}{|l|}{ Vasculitis } \\
\hline Yes & 2 & 100.0 & 10 & 62.5 & \multirow{3}{*}{$\begin{array}{l}\text { Exact Fisher } \\
p=0.5294\end{array}$} \\
\hline $\mathrm{NO}$ & 0 & 0.0 & 6 & 37.5 & \\
\hline Total & 2 & 100.0 & 16 & 100 & \\
\hline \multicolumn{6}{|l|}{ Panniculitis } \\
\hline Yes & 2 & 100.0 & 9 & 56.3 & \multirow{3}{*}{$\begin{array}{l}\text { Exact Fisher } \\
p=0.4967\end{array}$} \\
\hline No & 0 & 0.0 & 7 & 43.8 & \\
\hline Total & 2 & 100.0 & 16 & 100 & \\
\hline \multicolumn{6}{|l|}{ Neutrophils - Gradation } \\
\hline $1+$ & 0 & 0.0 & 0 & 0.0 & \multirow[t]{3}{*}{-} \\
\hline $2+$ & 2 & 100.0 & 16 & 100.0 & \\
\hline Total & 2 & 100.0 & 16 & 100 & \\
\hline \multicolumn{6}{|l|}{ Plasma cells - Gradation } \\
\hline $1+$ & 0 & 0.0 & 0 & 0.0 & \multirow[t]{3}{*}{-} \\
\hline $2+$ & 2 & 100.0 & 16 & 100.0 & \\
\hline Total & 2 & 100.0 & 16 & 100 & \\
\hline
\end{tabular}


a prevalence of borderline-borderline(BB) $(40.2 \%)$ and borderline-lepromatous (BL) (19.6\%) forms, consonant with findings from studies by Oliveira and collaborators and Longo and Cunha, performed in referral services in Minas Gerais and Mato Grosso do Sul, respectively. ${ }^{14,21}$

The expected histopathological findings, innate to each clinical form of leprosy, were present without modifications between the groups with or without HIV. The questions about histology preservation and the little influence of HIV on granuloma formation still need further elucidation. Ustianowski, Lawn and Lockwood, when addressing this issue, cited that it should be noted that HIV effects on immune cells can be somewhat compartmentalized and other cells may be recruited and activated to maintain the structure..$^{22}$

Dermis edema was present in all patients with reversal reaction in groups 1 and 2. However, when measured, it was observed that all coinfected patients had grade 2+ edema; whereas 14 patients with isolated leprosy had 1+ and 19 had grade 2+ edema $(p=0.0057)$. Many authors describe dermis edema as a fundamental histological feature in reversal reaction. ${ }^{8,11,13,23-26}$ Dermis edema is expected in such cases, because reversal reaction is a delayed-type hypersensitivity reaction, which reflects an excessive immune response against $M$. leprae, with vasodilation, increased production of cytokines, chemokines, endothelial adhesion molecules expression and lymphocytes and plasma extravasation.

Despite the more intense dermis edema, Group 1 (coinfected) presented more compact granulomas overall, with smaller percentage of fragmentation (fragmentation $11-50 \%$ ), corroborating the findings from Deps and colleagues (2013) ${ }^{1}$, in which a larger number of compact granulomas was reported in coinfected patients when compared to noncoinfected ones (Figure 4). At the same time, the majority of patients in Group $2(71.9 \%)$ had a degree of fragmentation higher than $50 \%(p=0.0001)$. This finding, perhaps, may be due to the fact that most patients with reversal reaction in Group 2 had BB clinical form, which is usually expressed by loose granulomas and eventually even with some degree ofedema within; different from coinfected patients, in which most type 1 reaction were BT clinical form cases, a form with better organized granulomas and no edema. ${ }^{11,13}$

Regarding the presence of giant cells, we observed that all patients in the coinfected group had giant cells in histopathological examinations graded as 2+. In the group with leprosy without HIV, 18 histopathological exams (54.5\%) showed no presence of giant cells $(\mathrm{p}=0.0006)$, and $14(93.3 \%)$ were classified as $1+(p<0.0001)$. Giant cells result from the fusion of activated macrophages in the attempt to destroy a foreign particle, and in the present study we found a large number of these cells, confirming their increased presence in type 1 reactional states. ${ }^{8,27}$

According to Ridley and Jopling (1966), these cells are present in varying quantities in the different clinical forms of leprosy. These two authors cite that BT and TT forms are those with the larger number of these cells, whereas in BB they are much scarcer. The explanation for the difference found between the groups may have the same link described for edema within the granuloma: in the group without coinfection, patients with reversal reaction had mostly BB clinical form, in which there are usually fewer giant cells, different from the coinfected group, in which most cases of reversal reactions occurred in patients with BT clinical form that has many giant cells for being closer to the tuberculoid pole, which present predominant Th1 cellular immune response. More organized tuberculous granulomas are formed in this area, and therefore with the chronic maintenance of cytokine signaling in this profile, an increased amount of activated macrophages join in the formation of giant cells.

Although HIV also infects macrophages, they are relatively resistant to the cytopathic effect of the virus. So it is likely that macrophages are not destroyed but impaired in their function, remaining activated for an extended time, which keeps them longer in the area to where they were recruited. ${ }^{28}$

Regarding ENL, we investigated: the presence of neutrophils, plasma cells, panniculitis, vasculitis and dermis edema, which are the most cited features in relation to this condition. ${ }^{926,29,30}$ Dermis edema was present in $9(56.3 \%)$ patients without HIV and in all the coinfected patients with ENL $(p=0.6606)$. Vasculitis was observed in 2 patients $(100 \%)$ in Group 1 and in 10 patients (62.5\%) in Group 2 ( $p=0.7864)$, whilst panniculitis occurred in 2 patients of Group 1 and in $9(56.3 \%)$ patients in Group 2. Regarding cellularity, neutrophils and plasma cells were found in all patients of both groups, and graded as $2+$.

The findings were similar with those by Adhe, Dongre and Khopkar, (2012), who observed the histopathological features of 42 patients with ENL in India and found neutrophils in 100\% of cases, dermis edema in $81 \%$ of patients, and also vasculitis and panniculitis in $69 \%$ of cases. ${ }^{24}$ Meanwhile, Sarita and colleagues (2013) demonstrated different results. ${ }^{26}$ Studying 14 ENL patients, also in India, these authors did not observe neutrophils nor edema in any of the patients and raised the assumption that these biopsies without neutrophils or edema were obtained from patients with longer clinical courses, already in chronic phases; however these patients with or without neutrophils/edema presented no differences in the clinical aspects of their lesions. The same explanation 
was used for patients presenting various degrees of vascular involvement, in which the most frequently observed signs were the presence of fibrin and neutrophils in the vascular walls. The literature cites various degrees of necrosis and septal and lobular mixed panniculitis, mainly in type 2 reactions such as erythema multiforme and Lucio's phenomenon. ${ }^{24,29}$ In the classical presentation of ENL in our study, necrosis was observed in 2 patients in Group 1 and 9 (56.3\%) patients in Group 2.

ENL involves a systemic inflammatory reaction secondary to immune complex deposition similar to Gell \& Coombs type III hypersensitivity reaction; the role of B lymphocytes is not yet fully understood, but it warrants the intense presence of plasma cells in the infiltrate. IL-1 $\beta$, also present in ENL cases, increases the expression of E-selectin and neutrophil migration to the site of acute inflammation; so these cells are more frequently observed when patients are biopsied early. ${ }^{26,28}$

The observations were similar in both groups, without significant differences in any of the evaluated features. Massone and colleagues (2011) also reported that the histopathological characteristics they found in a coinfection cases review were similar to those seen in cases of leprosy without HIV, citing the presence of edema, neutrophils, with or without vasculitis and lobular panniculitis over a pre-existing leprosy lesion. ${ }^{30}$ The impossibility of applying a multivariate analysis was a limitation of this study, which is mainly due to the small number of coinfected patients with ENL, preventing a more comprehensive comparison of the findings.

\section{CONCLUSIONS}

The study found few histopathological differences in reactional states between leprosy patients with or without HIV infection. The most significant differences occurred in the histopathological evaluation of reversal reaction, especially regarding the number of giant cells and the gradation of edema within the granuloma, however this fact should be analyzed considering the predominance of BT clinical form in the coinfected group and BB in the group of patients without HIV. It is noteworthy that patients with coinfection also showed the typical lesions of each clinical form of leprosy. Larger prospective studies in patients with HIV-leprosy coinfection are needed to confirm and broaden these results. 


\section{REFERENCES}

1. Deps P, Lucas S, Porro AM, Maeda SM, Tomimori J, Guidella C, et al. Clinical and histologica features of leprosy and human immunodeficiency virus coinfection in Brazil. Clin Exp Dermatol. 2013:38:470-7.

2. Ridley DS, Jopling WH. Classification of leprosy according to immunity: a five-group system Int J Lepr Other Mycobact Dis. 1966;34:255-73.

3. Caruso RL, Fernandes RM, Serra MS, Lima RB, Martins CJ. Atypical reversal reaction in a borderline leprosy patient coinfected with HIV. An Bras Dermatol. 2007;82:553-7.

4. Little D, Khanolkar-Young S, Coulthart A, Suneetha S, Lockwood DN. Immunohistochemica analysis of cellular infiltrate and gamma interferon, interleukin-12, and inducible nitric oxide synthase expression in leprosy type 1 (reversal) reactions before and during prednisolone treatment. Infect Immun. 2001;69:3413-7.

5. Walker SL, Lockwood DN.The clinical and immunological features of leprosy.Br Med Bull. 2006;77-78:103-21.

6. Xavier MB. Estudo clínico e imunopatológico em pacientes coinfectados pelo vírus da imunodeficiência humana [tese]. Belém (PA): Universidade Federal do Pará; 2006. 167f.

7. Massone C, Talhari C, Talhari S, Brunasso AM, Campbell TM, Curcic P, Cerroni L, et al. Immunophenotype Of Skin Lymphocytic Infiltrate In M.Leprae And Hiv Coinfected Patients: A Scenario Dependent Of Cd8(+) And/Or Cd20(+) Cells.Br J Dermatol. 2011;165:321-8.

8. Lockwood DN, Lucas SB, Desikan KV, Ebenezer G, Suneetha S, Nicholls P. The histological diagnosis of leprosy type 1 reactions: identification of key variables and an analysis of the process of histological diagnosis. J Clin Pathol. 2008:61:595-600.

9. Walker SL, Lockwood DN. Leprosy type 1 (reversal) reactions and their management. Lepr Rev. 2008;79:372-86

10. Brasil. Ministério da Saúde. Portaria GM/MS n. 3.125 de 7 de outubro de 2010.Aprova as diretrizes para vigilância, atenção e controle da hanseníase. Diário Oficial da União. 2010 out. 7.

11. Nery JAC, Sales AM, Illarramendi X, Dupre NC, Jardim MR, Machado AM. Contribution to diagnosis and management of reactional states: a practical approach. An Bras Dermatol 2006;:81:367-75

12. Lima MAR, Prata MO. Moreira D. Perfil da hanseníase no Distrito Federal no período de 2000 a 2005. Com Ciênc Saúde. 2008;19:163-70.

13. Menezes VM, Sales AM, Illarramendi X, Miranda A, Gonçalves Morgado M, Gutierrez-Galhardo $M C$, et al. Leprosy reaction as a manifestation of immune reconstitution inflammatory syndrome: a case series of a Brazilian cohort. AIDS. 2009;23:641-3.

14. Longo JDM, Cunha RV. Perfil clínico-epidemiológico dos casos de hanseníase atendidos no Hospital Universitário em Campo Grande, Mato Grosso do Sul, de janeiro de 1994 a julho de 2005. Hansen Int. 2006:31:9-14.

15. Kharkar V, Bhor UH, Mahajan S, Khopkar U. Type I lepra reaction presenting as immune reconstitution inflammatory syndrome. Indian J Dermatol Venereol Leprol. 2007;73:253-6.

16. Batista MD, Porro AM, Maeda SM, Gomes EE, Yoshioka MC, Enokihara MM, et al. Leprosy reversal reaction as immune reconstitution inflammatory syndrome in patients with AIDS. Clin Infect Dis. 2008;46:e56-60.

17. Trope MB, Lenzi MER, Maceira JP, Barroso PF, Oliveira MLW. Reação hansênica e síndrome de reconstituição imunológicana aids. Hansen Int. 2008;33:25-33.

18. Sarno EN, Illarramendi X, Nery JA, Sales AM, Gutierrez-Galhardo MC, Penna ML, et al. HIV-M leprae interaction: can HAART modify the course of leprosy? Public Health Rep. 2008;123:206-12.

19. Pereira GA, Stefani MM, Araújo Filho JA, Souza LC, Stefani GP, Martelli CM. Human immunodeficiency virus type 1 (HIV-1) and Mycobacterium leprae coinfection: HIV-1 subtypes and clinical, immunologic, and histopathologic profiles in a Brazilian cohort. Am J Trop Med Hyg. 2004;71:679-84

20. Talhari C, Mira MT, Massone C, Braga A, Chrusciak-Talhari A, Santos M, et al. Leprosy and HIV coinfection: a clinical, pathological, immunological, and therapeutic study of a cohort from a Brazilian referral center for infectious diseases. J Infect Dis. 2010;202:345-54
21. Oliveira TAP, Carvalho CL, Galiciolli R, Santangelo EM, Souza RA. Estudo das Incapacidades dos casos notificados de hanseníase em uma gerência regional de saúde do Vale do Jequitinhonha entre 2001 e 2008. Hansen Int. 2010;35:45-52.

22. Ustianowski AP, Lawn SD, Lockwood DN. Interactions between HIV infection and leprosy: a paradox. Lancet Infect Dis. 2006;6:350-60.

23. Trindade MA, Valente NY, Manini Ml, Takahashi MD, Anjos CF, Benard G, et al. Two patients coinfected with Mycobacterium leprae and human immunodeficiency virus type 1 and naive for antiretroviral therapy who exhibited type 1 leprosy reactions mimicking the immune reconstitution inflammatory syndrome. J Clin Microbiol. 2006;44:4616-8.

24. Adhe $\mathrm{V}$, Dongre A, Khopkar U. A retrospective analysis of histopathology of 64 cases of lepra reactions. Indian J Dermatol. 2012;57:114-7.

25. Walker SL, Saunderson P, Kahawita IP, Lockwood DN. International workshop on erythema nodosum leprosum (ENL)--consensus report; the formation of ENLIST, the ENL international study group. Lepr Rev. 2012;83:396-407.

26. Sarita S, Muhammed K, Najeeba R, Rajan GN, Anza K, Binitha MP, et al. A study on histological features of lepra reactions in patients attending the Dermatology Department of the Government Medical College, Calicut, Kerala, India. Lepr Rev. 2013;84:51-64.

27. Weedon D, Strutton G. Skin pathology. Edinburgh: Churchill livingstone; 2002. p. 765-72.

28. Abbas AK, Lichtman AH, Pillai S. Imunologiacelular e molecular. 7 ed. Rio de Janeiro: Elsevier; 2012.

29. Meyerson MS. Erythema nodosum leprosum. Int J Dermatol. 1996;35:389-92.

30. Massone C, Talhari C, Ribeiro-Rodrigues R, Sindeaux RH, Mira MT, Talhari S, et al. Leprosy and HIV coinfection: a critical approach.Expert Rev Anti Infect Ther. 2011;9:701-10.

\author{
MAILING ADDRESS: \\ Carla Andréa Avelar Pires \\ Av Generalíssimo Deodoro, 92 \\ Umarizal \\ 66055-240 - Belém - PA \\ Brazil \\ E-mail: carlaavelarpires@gmail.com
}

How to cite this article: Pires CAA, Miranda MFR, Bittencourt MJS, Brito AC, Xavier MB. Comparison between histopathologic features of leprosy in reaction lesions in HIV coinfected and non-coinfected patients. An Bras Dermatol. 2015;90(1):27-34. 